\section{Біохімічні і молекулярні механізми розвитку інсулінорезистентності в клітинах жирової тканини}

\section{Н.І. Левчук}

ДУ «Інститут ендокринології та обміну речовин ім. В.П. Комісаренка НАМН України»

Резюме. Інсулінорезистентність (IP) тісно пов'язана з ожирінням і $є$ ключовою ланкою в патогенезі цукрового діабету 2-го типу (ЦД2) та низки супутніх захворювань. Споживання надмірної кількості висококалорійної їжі та недостатня фізична активність призводить до накопичення жирової тканини переважно в абдомінальновісцеральній області. Вісцеральний жир є метаболічно активним. Його клітини виробляють низку біологічноактивних речовин і є місцем синтезу ферментів стероїдних гормонів. Висока метаболічна активність вісцеральної жирової тканини також пов'язана з наявністю в адипоцитах високої щільності $\beta_{3}$-адренорецепторів, кортикостероїдних і андрогенних рецепторів та відносно низької щільності а рів до інсуліну. Збільшення об'єму вісцеральної жирової тканини призводить до активного ліполізу, що супроводжується утворенням великої кількості вільних жирних кислот (ВЖК), синтезу прозапальних цитокінів (інтерлейкін-6 (ІЛ-6), інтерлейкін-1бета (ІЛ-1ß) і фактор некрозу пухлин альфа (ФНП-а)) та розвитку хронічного системного запалення. Всі ці події призводять до розвитку IP - стану, що характеризується зниженням чутливості периферичних тканин організму до дії інсуліну. Результати ґрунтовного аналізу наукової літератури дають змогу стверджувати, що вивчення молекулярних механізмів розвитку IP має важливе практичне значення для удосконалення і розробки нових методів діагностики та лікування осіб із надмірною масою жирової тканини. У даному огляді літератури розглянуто біохімічні і морфологічні особливості структури жирової тканини, ії метаболічну активність, а також механізми формування стану клітинної ІР на рецепторному і пострецепторному рівнях. Наведено дані про участь запального процесу в розвитку IP.

Ключові слова: інсулінорезистентність, абдомінально-вісцеральне ожиріння, адипоцити, запалення, прозапальні цитокіни.

Останніми роками значна увага експериментаторів та діабетологів приділяється вивченню механізмів розвитку IP. На сьогодні

\footnotetext{
* Адреса для листування (Correspondence): ДУ «Інститут ендокринології та обміну речовин ім. В.П. Комісаренка НАМН України», вул. Вишгородська, 69, м. Київ, 04114 україна. E-mail: levnataly@meta.ua

(с) H.I. Левчук
}

доведено, що IP є ключовим чинником розвитку не лише ЦД2, але й багатьох інших захворювань, зокрема атеросклерозу, артеріальної гіпертензії, хвороби Альцгеймера, полікістозу яєчників, неалкогольної жирової хвороби печінки, деяких форм раку [1-7]. Під терміном 
«інсулінорезистентність» розуміють зниження чутливості периферичних тканин (скелетних м’язів, печінки і жирової тканини) до дії інсуліну. Як відомо, біологічний ефект інсуліну полягає в утилізації глюкози крові периферичними клітинами. Унаслідок зниження фізіологічної дії інсуліну на клітини-мішені збільшується його секреція $\beta$-клітинами острівців Лангерганса підшлункової залози, формується компенсаторна гіперінсулінемія. За розвитку IP виникає стан відносної інсулінової недостатності, що проявляється підвищенням рівня глюкози в крові, i, як наслідок, порушуються основні метаболічні процеси в організмі - вуглеводний, білковий і жировий обміни, синтез ДНК, РНК, диференціювання і ріст клітин організму [8]. У подальшому формується порушення толерантності до вуглеводів (переддіабет) та 3 часом розвивається явний ЦД2 з клінічною маніфестацією [9].

На жаль, дотепер не існує єдиної концепції розвитку IP. Одним із найважливіших чинників, що ініціює IP, є збільшення маси тіла за рахунок надлишкового накопичення жирової тканини, яке зумовлене надмірним споживанням висококалорійної їжі та обмеженням фізичної активності. Споживання їжі, незбалансованої за вмістом жирів та вуглеводів, призводить до розвитку абдомінально-вісцерального ожиріння. Такий тип ожиріння характеризується надмірним утворенням жирової тканини навколо внутрішніх органів черевної порожнини.

Одним із критеріїв оцінки маси тіла є його індекс маси тіла (IMT), який розраховується як відношення маси тіла (у кілограмах) до зросту (у метрах, зведених у квадрат). Якщо IMT є вищим за 25, це вказує на наявність зайвої ваги; понад $30-\epsilon$ ознакою ожиріння. Проте IMT не враховує різницю між жировою та м'язовою масою, тому не може бути абсолютно точним показником стану тіла. Надійною ознакою надлишкового накопичення жирової тканини в абдомінальній ділянці є обвід талії і співвідношення обводу талії до обводу стегон (щоб отримати цей коефіцієнт, потрібно виміряти ці показники в сантиметрах та поділити між собою): $>94$ см і 0,9 для чоловіків і $>80$ см і $>0,8$ відповідно для жінок [10]. Нещодавно запропоновано для використання в клініці новий розрахунковий показник для визначення дисфункції вісцеральної жирової тканини, асоційованого з кардіометаболічним ризиком, - індекс вісцерального ожиріння (IBO). Це статевоспецифічний показник, який об'єднує параметри обводу талії, IMT, тригліцериди, ліпопротеїди високої щільності й одночасно враховує характер розподілу та метаболічну функцію жирової тканини [11]. Тому вважається, що основним критерієм розвитку IP є не лише збільшення маси жирової тканини, але й характер розподілу та функціональна активність жирової тканини в організмі.

Таким чином, ожиріння є фактором ризику формування IP та тяжких супутніх захворювань, ранньої інвалідизації, передчасного старіння і скорочення тривалості життя.

Морфологічні та біохімічні особливості структури жирової тканини за умов розвитку інсулінорезистентності

Встановлено, що ожиріння, яке поєднане 3 IP, характеризується морфологічними особливостями. Так, в експериментах на щурах із використанням висококалорійної їжі впродовж трьох місяців методом світової мікроскопії було виявлено, що кількість і розмір адипоцитів, а також розмір їх ядер у зразках жирової тканини сальника тварин були значно збільшеними [12]. Присутні адипоцити неправильної форми. Масова частка жирової тканини збільшена, тоді як позаклітинного матриксу - зменшена. За допомогою електронної мікроскопії продемонстровано потовщення базальної пластинки та збільшення кількості ліпідних включень. Таким чином, висококалорійна дієта індукувала збільшення маси тіла щурів завдяки гіпертрофії та гіперплазії адипоцитів. При ожирінні відбувається не лише збільшення розмірів та кількості адипоцитів, а й інфільтрація макрофагами жирової тканини, яка є обов'язковим компонентом розвитку запального процесу, унаслідок чого змінюється метаболічна активність жирової тканини $[13,14]$.

За IP в адипоцитах також простежуються значні структурні зміни їх клітинних мембран. Методами тонкошарової та газорідинної хроматографії було встановлено, що рівень вільного холестерину значно підвищувався в адипоцитах щурів 3 індукованою ожирінням IP порівняно 3 контрольними тваринами. Аналіз фосфоліпідного складу засвідчив зменшення вмісту фосфатидилхоліну та сумарної 
кількості фосфатидилінозитолу й фосфатидилсерину в адипоцитах IP-тварин, тоді як кількість лізофосфатидилхоліну, сфінгомієліну та фосфатидилетаноламіну збільшувалася в групі IР-щурів порівняно з контрольною [15].

Спостерігається підвищення ангіогенної активності жирової тканини, що є важливим фактором її росту. Ініціатором іï збільшення на початковому етапі виступає гіпоксія. Як тільки вага тіла людини з ожирінням досягає оптимального рівня, швидкість росту судин жирової тканини знижується. Це зумовлено пригніченням рівня експресії ангіогенних факторів, зокрема ендотеліального фактора росту судин (VEGF), який індукується гіпоксією на початковому етапі ожиріння і тромбоцитарного фактора росту (PDGF) [16]. За умов ожиріння також пригнічується експресія генів основних факторів ангіогенезу (VEGF-A, PDGFC, фактора росту фібробластів 2 (FGF2) та подібного до рецептора фактора росту фібробластів 1 (FGFRL1)), але збільшується рівень експресії генів FGF1, рецептора-2 фактора росту фібробластів (FGFR2), транскрипційного фактора 8 родини Е2F (E2F8) i фактора 1A, що індукується за гіпоксією (HIF1A) [17]. Порушення толерантності до глюкози за умов ожиріння асоціюється з підвищенням рівня експресії генів FGF2, FGF1, E2F8, VEGF-A і його сплайс-варіанту 189 та зниженням рівня експресії гену FGFR2. Отже, IP жирової тканини проявляється збільшенням розмірів та кількості адипоцитів, змінами фосфоліпідного складу плазматичних мембран, наявністю запалення, а також зміною рівня експресії ангіогенних факторів і генів, які кодують ключові фактори ангіогенезу.

Метаболічна активність жирової тканини та їі роль у розвитку інсулінорезистентності

Раніше вважалося, що жирова тканина в організмі виконує лише функції енергозбереження, теплоізоляції і захисту від механічних зовнішніх впливів. Наразі ii розглядають як самостійний ендокринний орган, що синтезує широкий спектр біологічно активних речовин, які беруть участь у регуляції процесу коагуляції, апетиту, імунітету, репродукції, ангіогенезу, фібринолізу, тонусу судин і контролю маси тіла [18]. Серед них лептин, адипонектин, адипсин, апелін, резистин, ангіотензиноген, вісфантин, ФНП- $\alpha$, ІЛ-6, інгібітор активатора плазміногену 1 (PAI-1), VEGF, інсуліноподібний фактор росту 1 (IФР-1), ліпопротеїнова ліпаза, статеві і глюкокортикоїдні гормони та ін. [18]. I це не повний список речовин, які продукує жирова тканина. Він періодично доповнюється. Встановлено, що розвиток IP при вісцеральному ожирінні пов'язаний зі збільшенням синтезу лептину, ФНП- $\alpha$, ІЛ-6, резистину, апеліну, вісфантину та зі зниженням рівня речовини, яка запобігає розвитку IP адипонектину [19-23].

Висока метаболічна активність вісцеральної жирової тканини пов'язана 3 наявністю в адипоцитах високої щільності $\beta_{3}$-адренорецепторів, кортикостероїдних і андрогенних рецепторів та відносно низької щільності $\alpha_{2}$-адренорецепторів і рецепторів до інсуліну. Ці особливості визначають високу чутливість вісцеральної жирової тканини до ліполітичної дії катехоламінів і низьку - до антиліполітичної дії інсуліну. Це призводить до активізації ліполізу у вісцеральній жировій тканині і надходженню великої кількості ВЖК у портальну циркуляцію, а потім у системний кровообіг. Висока концентрація ВЖК у портальній вені порушує функцію печінки і викликає розвиток дисліпідемії [24]. Крім того, тривала циркуляція ВЖК призводить до пригнічення глюкозоіндукованої секреції інсуліну $\beta$-клітинами підшлункової залози з подальшим ї апоптозом, розвитку IP у скелетних м'язах і ендотелії судин [25-27]. Даний комплекс патологічних подій отримав назву «ліпотоксичність».

Жирова тканина є місцем синтезу ферментів стероїдних гормонів, які залучені до ростової стимуляції жирової тканини та прогресування IP. В експериментах на сирійських хом'ячках (Mesocricetus auratus) обох статей віком 1 і 2,5 місяці, які отримували висококалорійну дієту впродовж 6 тижнів, досліджували вплив інгібіторів ароматази (фермент, який відповідає за перетворення андрогенів у естрогени) різної структури на показники загальної маси тіла, вміст білка в жировій тканині та їх кореляцію [28]. Введення летрозолу впродовж 21 дня в дозі 0,309 мг/кг призводило до вірогідного зменшення середньої маси тіла в усіх підгрупах (у молодих самців - на 26,5\%, у зрілих - на 24,9\%, у молодих самиць - на $34,5 \%$, 
у зрілих - на 24,0\%) і відповідного збільшення вмісту білка у вісцеральній жировій тканині (у молодих самців - на 11,5\%, у зрілих - на $46,0 \%$, у молодих самиць - на $33,5 \%$, у зрілих на 44,8\%) з високим коефіцієнтом кореляції. Інгібітори ароматази третього покоління (летрозол, екземестан і анастрозол) призводили до вірогідного зменшення кількості прийомів і середнього часу харчування та сироваткового вмісту лептину у всіх досліджуваних гендерно-вікових групах. Таким чином, інгібітори ароматази зменшували середню масу тіла, прояви гіперфагії та лептинорезистентності на тлі метаболічного синдрому [29].

Підвищений рівень експресії $17 \beta$-гідроксистероїддегідрогенази (17 $\beta$-ГСД) також є характерним для вісцеральної жирової тканини. Іїі функція полягає в перетворенні андростендіону в тестостерон і естрону в естрадіол. Співвідношення 17 $\beta$-ГСД і ароматази позитивно корелює із центральним ожирінням і свідчить про локальне збільшення продукції андрогенів у вісцеральному жировому депо [30].

Наразі все більше уваги приділяється вивченню метаболізму глюкокортикоїдів у жировій тканині, останні результати за цим напрямом підсумовано в огляді [31]. У вісцеральній тканині міститься фермент $11 \beta$ гідроксистероїддегідрогеназа-1 (11ß-ГСД1), який каталізує перетворення кортизону в кортизол. Експериментально підтверджено, що екзогенне введення кортикостерону мишам лінії C57BL/6J у дозі 100 мкг на тварину впродовж 3 тижнів призводило до підвищення активності 11- $\beta$-ГСД1 і гексозо-6-фосфат дегідрогенази(Г6ФД) (фермент, що каталізує перетворення глюкози-6-фосфату до 6-фосфоглюконату), зростання рівня експресії мРНК гормончутливої ліпази і жирової тригліцеридної ліпази в адипоцитах [32]. Виявлені зміни супроводжувались збільшенням маси тіла, гіперглікемією, гіперліпідемією, гіперінсулінемією. Встановлено, що підвищення рівня експресії 11ß-ГСД1 в адипоцитах опосередковується через активацію с-Jun N-термінальної протеїнкінази (JNK) [33].

Можливі механізми розвитку IP в адипоцитах жирової тканини

Інсулін - гормон пептидної природи, що утворюється в бета-клітинах острівців Лангерганса підшлункової залози. Він впливає на багато процесів у клітинах тканин-мішеней, але найважливіша його дія полягає в зниженні концентрації глюкози в крові. Цей ефект реалізується через зв'язування гормону з рецепторами на плазматичній мембрані клітини-мішені. Інсуліновий рецептор складається 3 двох позаклітинних $\alpha$-субодиниць i двох трансмембранних $\beta$-субодиниць, які є глікопротеїнами, зв'язаними між собою дисульфідними зв'язками [34]. За механізмом дії рецептор інсуліну є тирозиновою протеїнкіназою, яка фосфорилює білки за ОН-групами тирозину. Приєднання інсуліну до центру зв'язування $\alpha$-субодиниці призводить до автофосфорилювання $\beta$-субодиниці. Протеїнкіназа починає фосфорилювати внутрішньоклітинні білки, змінюючи їню активність. Ключовим білком, що фосфорилюється тирозиновою протеїнкіназою, є субстрат інсулінового рецептора (CIP), який у фосфорильованому стані може активувати білки, необхідні для регуляції клітинних процесів.

Виділяють два основних шляхи реалізації біологічної дії інсуліну - фосфатидилінозитол-3-кіназний шлях (PI3K/Akt), який переважно відповідає за метаболічну дію інсуліну, та шлях мітоген-активуючих протеїнкіназ (МАРК) - регулює експресію генів, які контролюють ріст і диференціацію клітин [35].

На клітинному рівні передумовою для формування IP є декілька механізмів, які реалізуються на рецепторному і пострецепторному рівнях.

\section{1. Рецепторний рівень інсулінорезистент-} ності. За результатами досліджень останніх років серед механізмів, які зумовлюють розвиток IP в адипоцитах, значна роль відводиться рецепторному механізму. Встановлено, що формування IP у жировій тканині пов'язано зі зміною кількості рецепторів до інсуліну. У дослідах на експериментальних щурах, які перебували на довготривалій висококалорійній дієті впродовж 18 тижнів, методом імуноферментного аналізу з використанням моноклональних антитіл проти $\beta$-субодиниці інсулінового рецептора виявлені різноспрямовані зміни вмісту інсулінового рецептора в мембранній фракції та цитозолі адипоцитів [36]. Його зниження в мембранній фракції жирової тканини, можливо, зумовлено порушеннями цілісності ліпідного бішару клітин через посилення пероксидації. Підвищення 
вмісту інсулінового рецептора в цитозолі адипоцитів може вказувати на активацію його синтезу, але внаслідок ушкодження плазматичної мембрани, імовірно, порушується внутрішньоклітинна транслокація інсулінового рецептора, за рахунок чого новосинтезовані молекули рецептора не надходять до мембрани і накопичуються в цитозолі. Це може вказувати на те, що розвиток IP на пізніх термінах експерименту, імовірно, є наслідком порушення функціонування клітин жирової тканини [36].

Дослідження зразків тканини підшкірної жирової клітковини і фрагмента сальника людини продемонстрували, що в пацієнтів із нормальною масою тіла в різних типах жирової тканини кількість клітин, що продукують рецептори до інсуліну, відрізняється. У підшкірній жировій тканині кількість клітин, які експресують рецептори до інсуліну, вірогідно більша, ніж у вісцеральній жировій тканині. 3 прогресуванням ожиріння кількість клітинпродуцентів інсулінового рецептора вірогідно зменшується в усіх типах жирової тканини, але цей процес у вісцеральній тканині виражений значно сильніше [37].

Не виключено, що в індукції IP має значення не лише кількість рецепторів у клітинній мембрані адипоциту, але й зниження їх спорідненості до зв'язування з природним йому лігандом - інсуліном. Показано, що дисбаланс ліпідного складу адипоцитів, можливо, впливає на фізико-хімічні властивості їх плазматичних мембран i, як наслідок, функціональну активність трансмембранних білків [15]. Таким чином, при порушенні рецепторного апарату клітини розпізнавання інсуліну не відбувається і транспорт глюкози в клітину порушується, внаслідок чого розвивається гіперглікемія. Це створює умови для формування та прогресування IP і подальшого розвитку цілого комплексу метаболічних розладів.

2. Пострецепторний рівень інсулінорезистентності. Чисельні експериментальні дослідження переконливо свідчать, що в переважній більшості порушення, які є поштовхом для індукції IP, пов’язані з внутрішньоклітинною сигналізацією інсуліну. Це роз’єднання відбувається на рівні CIP, що виступає посередником між рецептором і РІ3К та слугує місцем посадки низки сигнальних молекул-мішеней рецептора інсуліну. Для інсулін-нечутливих клітин характерно підвищене фосфорилювання CIP за залишком серину. Це перешкоджає фосфорилюванню СIP за залишком тирозину, що є необхідною умовою для трансдукції сигналу від рецептора до генетичного апарату клітини. До складу СІР входить велика кількість серинових залишків, які є головними мішенями для різноманітних протеїнкіназ. Серед них стрес-активуючі кінази (протеїнкіназа, що регулюється позаклітинними сигналами (ERK), JNK, АМФ-залежна протеїнкіназа (АМРК)), прозапальна IкB-кіназа (IKK) та сигнальний каскад Akt/mTOR/p70S6K1 [38].

На молекулярному рівні інгібіторний ефект серинового фосфорилювання реалізується різними шляхами, серед них дисоціація CIP від інсулінового рецептора, підвищення деградації СІР, блокування тирозинового фосфорилювання CIP і вивільнення з комплексу з СIP адапторних білків [38]. Основним результатом пригнічення фосфорилювання за тирозиновими залишками є активація шляхів, які перешкоджають передачі сигналів від інсуліну та призводять до зниження відповіді на дію гормону. За умов розвитку IP в адипоцитах знижується експресія CIP-1 та глюкозного транспортера типу 4 (ГЛЮТ-4), тим самим сприяючи розвитку IP $[39,40]$.

Роль запалення в розвитку інсулінорезистентності жирової тканини

За результатами досліджень останніх років встановлено, що надлишкове накопичення метаболічно активної жирової тканини призводить до хронічного системного запалення завдяки залученню до неї макрофагів, які виділяють прозапальні цитокіни та стимулюють їх активацію. На сьогодні механізм, який би пояснював збільшення інфільтрації макрофагів в адипозну тканину при ожирінні залишається майже не дослідженим. Згідно з даними літератури, на початковому етапі гіпертрофічні адипоцити починають виділяти низький рівень ФНП- $\alpha$, який, у свою чергу, стимулює преадипоцити до вироблення моноцитарного хемоатрактантного білка 1 (МСР-1) (рис.) [13].

Крім преадипоцитів, цей білок також синтезують ендотеліальні клітини жирової тканини у відповідь на дію цитокінів. Можливо, преадипоцити та ендотеліальні клітини завдяки активній секреції МСР-1 залучають до інфільтрації макрофагів у жирову тканину (рис.). Макро- 


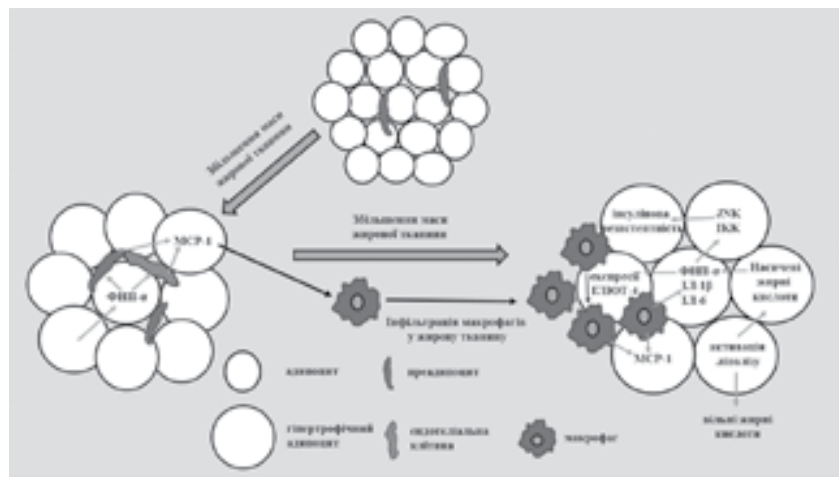

Рис. Схема розвитку запального процесу в жировій тканині (Capurso C, Capurso A. 2012, модифіковано)

Fig. Diagram of development of the inflammatory process in adipose tissue (Capurso C, Capurso A. 2012, modification)

фаги в жировій тканині є основним джерелом вироблення прозапальних цитокінів (ІЛ-6, ІЛ-1 $\beta$ і ФНП- $\alpha)$ та МСР-1. Активна інфільтрація макрофагами жирової тканини призводить до їі збільшення і, як наслідок, порушення функції адипоцитів. ІЛ-6, ІЛ-1 $\beta$ і ФНП- $\alpha$, у свою чергу, активують JNK та IKK. Ці кінази індукують IP шляхом підвищеного фосфорилювання залишку серину в 307-312 положеннях CIP-1 [13]. На синтез ФНП- $\alpha$ можуть впливати насичені жирні кислоти, зокрема лауринова, пальмітинова і стеаринова, які виробляються гіпертрофованими адипоцитами внаслідок активації ліполізу. Збільшення рівня ФНП- $\alpha$ в клітині опосередковується активацією тол-подібними рецепторами 4-го типу (TLR4) - мембранними білками, що відіграють важливу роль у формуванні вродженого імунітету [41]. Водночас ФНП- $\alpha$ призводить до гальмування експресії ГЛЮТ-4 в адипоцитах [42]. Отже, вісцеральна жирова тканина через синтез прозапальних цитокінів задіяна в патогенезі розвитку запального процесу та спричиняє прогресуванню IP.

Таким чином, жирова тканина є ендокринним органом, який бере участь у багатьох метаболічних процесах в організмі. Дисфункція жирової тканини призводить до розвитку надмірної маси тіла i, як наслідок, формуванню IP та цілої низки супутніх захворювань. Тому розуміння молекулярних механізмів індукції IP на тлі ожиріння має вагоме значення для профілактики та його лікування, а також розробки нових більш ефективних терапевтичних засобів для запобігання розвитку ускладнень, пов'язаних з ожирінням.

\section{Список використаної літератури}

1. Czech MP. Insulin action and resistance in obesity and type 2 diabetes. Nat Med. $2017 \mathrm{Jul} ; 23(7): 804-814$.

2. Beverly JK, Budoff MJ. Atherosclerosis: pathophysiology of insulin resistance, hyperglycemia, hyperlipidemia, and inflammation. J Diabetes. 2020 Feb;12(2):102-104.

3. Soleimani M. Insulin resistance and hypertension: new insights. Kidney Int. 2015 Mar;87(3):497-9.

4. Neth BJ, Craft S. Insulin resistance and Alzheimer's disease bioenergetic linkages. Front Aging Neurosci. 2017 Oct;9:345.

5. Williams T, Mortada R, Porter S. Diagnosis and treatment of polycystic ovary syndrome Am. Fam. Physician. 2016 Jul;94(2):106-13.

6. Kitade H, Chen G, Ni Y, Ota T. Nonalcoholic fatty liver disease and insulin resistance: new insights and potential new treatments. Nutrients. 2017 Apr;9(4):387.

7. Dev R, Bruera E, Dalal S. Insulin resistance and body composition in cancer patients. Ann Oncol. 2018 Feb;29(suppl_2): ii18-ii26.

8. Тронько НД, Соколова ЛК, Ковзун ЕИ, Пастер ИП. Инсулинотерапия: вчера, сегодня, завтра. Киев: Медкнига, 2014. 192 с. (Tronko ND, Sokolova LK, Kovzun EI, Pasteur IP. Insulin therapy: yesterday, today, tomorrow. Kyiv: Medical book, 2014. 192 c.)

9. Petersen MC, Shulman GI. Mechanisms of insulin action and insulin resistance. Physiol Rev. 2018 Oct;98(4):2133-2223.

10. Obesity: preventing and managing the global epidemic. Report of a WHO Consultation. Geneva, 2000. 268 p.

11. Amato MC, Giordano C, Pitrone M, Galluzzo A. Cut-off points of the visceral adiposity index (VAI) identifying a visceral adipose dysfunction associated with cardiometabolic risk in a Caucasian Sicilian population. Lipids Health Dis. 2011 Oct;10:183.

12. Aslan H, Altunkaynak BZ, Altunkaynak ME, Vuraler O, Kaplan S, Unal B. Effect of a high fat diet on quantitative features of adipocytes in the omentum: an experimental, stereological and ultrastructural study. Obes Surg. 2006 Nov;16(11):1526-34.

13. Capurso C, Capurso A. From excess adiposity to insulin resistance: The role of free fatty acids. Vascul Pharmacol. 2012 Sep-Oct;57(2-4):91-7.

14. Makki K, Froguel P, Wolowczuk I. Adipose tissue in obesityrelated inflammation and insulin resistance: cells, cytokines, and chemokines. ISRN Inflammation. 2013 Dec;2013:139239.

15. Dziuba OS, Hudz IeA, Kosiakova HV, Horid'ko TM, Klimashevsky VM, Hula NM. The effect of N-stearoylethanolamine on adipocytes free cholesterol content and phospholipid composition in rats with obesity-induced insulin resistance. Ukr.Biochem.J. 2018 Sep-Oct;90(5):81-90

16. Pang C, Gao Z, Yin J, Zhang J, Jia W, Ye J. Macrophage infiltration into adipose tissue may promote angiogenesis for adipose tissue remodeling in obesity. Am J Physiol Endocrinol Metab. 2008 Aug;295(2): E313-E22.

17. Minchenko OH, Bashta YM, Minchenko DO, Ratushna OO. Glucose tolerance in obese men is associated with dysregulation of some angiogenesis-related gene expressions in subcutaneous adipose tissue. Physiologycal Journal; 2016;62(2):12-23.

18. Coelho M, Oliveira T, Fernandes R. Biochemistry of adipose tissue: an endocrine organ. Arch Med Sci. 2013 Apr;9(2):191-200.

19. Chen L, Chen R, Wang H, Liang F. Mechanisms linking Inflammation to insulin resistance. Int J Endocrinol. 2015 Jun;2015:508409.

20. Nourbakhsh M, Nourbakhsh M, Gholinejad Z, Razzaghy-Azar M. Visfatin in obese children and adolescents and its association with insulin resistance and metabolic syndrome. Scand J Clin Lab Invest. 2015 Apr;75(2):183-8.

21. Bertrand C, Valet P, Castan-Laurell I. Apelin and energy metabolism. Front Physiol. 2015 Apr;6:115.

22. Moonishaa TM, Nanda SK, Shamraj M, Sivaa R, Sivakumar P, Ravichandran K. Evaluation of Leptin as a Marker of Insulin Resistance in Type 2 Diabetes Mellitus. Int J Appl Basic Med Res. 2017 Jul-Sep;7(3):176-180.

23. Wueest S, Konrad D. The role of adipocyte-specific IL-6-type cytokine signaling in FFA and leptin release. Adipocyte. 2018 Aug;7(3):226-8.

24. Saponaro C, Gaggini M, Carli F, Gastaldelli A. The subtle balance between lipolysis and lipogenesis: a critical point in metabolic homeostasis. Nutrients. 2015 Nov; 7(11):9453-74.

25. Oh YS, Bae GD, Baek DJ, Park E-Y, Jun H-S. Fatty acid-induced 
lipotoxicity in pancreatic beta-cells during development of type 2 diabetes. Front Endocrinol (Lausanne). $2018 \mathrm{Jul} ; 9: 384$.

26. Rachel LI. Free Fatty Acids and Skeletal Muscle Insulin Resistance. Prog Mol Biol Transl Sci. 2014;121:267-92.

27. Ghosh A, Gao L, Thakur A, Siu PM, Lai CWK. Role of free fatty acids in endothelial dysfunction. J Biomed Sci. 2017 Jul;24(1):50.

28. Загайко АЛ, Литкін ДВ, Стрельченко КВ. Вплив інгібіторів ароматази на вміст загального білка вісцеральної жирової тканини при метаболічному синдромі у хом'ячків. Український біофармацевтичний журнал. 2017;4(51):31-38. (Zagayko A Lytkin D, Strelchenko K. Aromatase inhibitors effect on the total protein content of visceral adipose tissue in hamsters with metabolic syndrome. Ukraïns'kij bìofarmacevtičnij žurnal. 2017;4(51):31-38).

29. Литкін ДВ. Вплив інгібіторів ароматази третього покоління на харчову поведінку на тлі експериментального метаболічного синдрому. Український біофармацевтичний журнал. 2018;4(57):59-62. (Lytkin D. The effect of the third-generation aromatase inhibitors on eating behavior in experimental metabolic syndrome. Ukraïns'kij bìofarmacevtičnij žurnal. 2018; 4(57):59-62)

30. DiSilvestro D, Petrosino J, Aldoori A, Melgar-Bermudez E, Wells A, Ziouzenkova O. Enzymatic intracrine regulation of white adipose tissue. Horm Mol Biol Clin Investig. 2014 Jul;19(1):39-55.

31. Akalestou E, Genser L, Rutter GA. Glucocorticoid metabolism in obesity and following weight loss. Front. Endocrinol (Lausanne) 2020 Feb;11:59.

32. Wang Y, Yan C, Liu L, et al. 11ß-Hydroxysteroid dehydrogenase type 1 shRNA ameliorates glucocorticoid-induced insulin resistance and lipolysis in mouse abdominal adipose tissue. Am J Physio Endocrinol Metab. 2015 Jan;308(1): E84-E95.

33. Peng K, Pan Y, Li J, et al. 11ß-Hydroxysteroid dehydrogenase type $1(11 \beta$-ГСД1) mediates insulin resistance through JNK activation in adipocytes. Sci Rep. 2016 Nov;6:37160.

34. Lee J, Pilch PF. The insulin receptor: structure, function, and signaling. Am J Physiol. 1994 Feb;266(2 Pt 1): C319-34.

35. Yung JHM, Giacca A. Role of c-Jun N-terminal Kinase (JNK) in obesity and type 2 diabetes. Cells. 2020 Mar; 9(3):706.

36. Кондро ММ, Галенова ТІ, Кузнєцова МЮ, Савчук ОМ. Експресія інсулінового рецептора у субклітинних фракціях м'язової та жирової тканин як фактор розвитку тканинної інсулінорезистентності у щурів за умов висококалорійної дієти. Фізіологічний журнал. 2013;59(2):59-64. (Kondro MM, Galenova TI, Kyznecova MU, Savchyk OM. Expression changes in insulin receptor in subcellular fractions of muscular and adipose tissue as the factor of the tissue insulin resistance development in rats under conditions of the high-energy diet. 2013;59(2):59-64).

37. Милиця КМ, Сорокіна IB, Мирошниченко МС, Плітень ОМ Порівняльна характеристика експресії інсулінових рецепторів у підшкірному депо і сальнику в осіб з метаболічним синдромом і ожиріння. Вісник морфології. 2017;23(1):9-11. (Mylytsya KM, Sorokina IV, Miroshnichenko MS, Pliten OM Comparative characteristics of expression insulin receptors in the subcutaneous fat depots and the appendage in patients with obesity and metabolic syndrome. Visnuk morfologii. 2017;23(1):9-11).

38. Ткачук ВА, Воротников АВ. Молекулярные механизмы развития резистентности к инсулину. Сахарный диабет. 2014;(2):2940. (Tkachuk VA, Vorotnikov AV. Molecular mechanisms of insulin resistance development. Diabetes. 2014;(2):29-40).

39. Seraphim PM, Nunes MT, Machado UF. GLUT4 protein expression in obese and lean 12-month-old rats: insights from different types of data analysis. Braz J Med Biol Res. 2001 Oct;34(10):1353-62.

40. Rondinone C, Wang L-M, Lonnroth P, Wesslau C, Pierce JH, Smith U. Insulin receptor substrate (IRS) 1 is reduced and IRS-2 is the main docking protein for phosphatidylinositol 3-kinase in adipocytes from subjects with non-insulin-dependent diabetes mellitus. Proc Natl Acad Sci USA. 1997 Apr;94(8):4171-5.

41. Watanabe Y, Nagai Y, Takatsu K. Activation and regulation of the pattern recognition receptors in obesity-induced adipose tissue inflammation and insulin resistance. Nutrients. 2013 Sep;5(9):3757-78.

42. Hube F, Hauner $\mathrm{H}$. The two tumor necrosis factor receptors mediate opposite effects on differentiation and glucose metabolism in human adipocytes in primary culture. Endocrinology. $2000 \mathrm{Jul} ; 141(7): 2582-8$.

(Надійшла до редакиії 14.07.2020 р.)

\section{Биохимические и молекулярные механизмы развития инсулинорезистентности в клетках жировой ткани}

\author{
Н.И. Левчук \\ ГУ «Институт эндокринологии и обмена веществ им. В.П. Комиссаренко \\ НАМН Украины»
}

Резюме. Инсулинорезистентность (ИР) тесно связана с ожирением и является ключевым звеном в патогенезе сахарного диабета 2-го типа (СД2) и ряда сопутствующих заболеваний. Потребление чрезмерного количества высококалорийной пищи и недостаточная физическая активность приводит к накоплению жировой ткани преимущественно в абдоминально-висцеральной области. Висцеральный жир является метаболически активным.

Его клетки вырабатывают ряд биологически активных веществ и является местом синтеза ферментов стероидных гормонов. Высокая метаболическая активность висцеральной жировой ткани также связана с наличием в адипоцитах высокой плотности $\beta_{3}$ адренорецепторов, кортикостероидных, андрогенных рецепторов и относительно низкой плотности $\mathrm{a}_{2}$-адренорецепторов и рецепторов к инсулину. Увеличение объема висцеральной жировой ткани приводит к активному липолизу, что сопровождается образованием большого количества свободных жирных кислот (СЖК), синтеза провоспалительных цитокинов (интерлейкин-б (ИЛ-6), интерлейкин-1бета (ИЛ-1ß), фактор некроза опухолей альфа (ФНО-а)) и развития хронического системного воспаления. Все эти события приводят к развитию ИР - состояния, характеризующегося снижением чувствительности периферических тканей организма к действию инсулина. Результаты детального анализа научной литературы позволяют утверждать, что изучение молекулярных механизмов развития ИР имеет важное практическое значение для усовершенствования и разработки новых методов диагностики и лечения лиц с избыточным весом жировой ткани. В данном обзоре литературь рассмотрены биохимические и морфологические особенности структуры жировой ткани, ее метаболическую активность, а также механизмы, которые обусловливают формирование состояния клеточной ИР на рецепторном и пострецепторном уровнях. Приведены данные об участии воспалительного процесса в развитии ИР.

Ключевые слова: инсулинорезистентность, абдоминально-висцеральное ожирение, адипоциты, воспаление, провоспалительные цитокины.

\section{Biochemical and molecular mechanisms of the development of insulin resistance in adipose tissue cells}

\section{N.I. Levchuk}

SI «V.P. Komisarenko Institute of Endocrinology and Metabolism, Natl. Acad. Med. Sci. of Ukraine»

Abstract. Obesity - associated insulin resistance (IR) is a key link in the pathogenesis of type 2 diabetes and a number of comor- 


\section{Огляди}

bidities. Consumption of excessive amounts of high-calorie food and insufficient of physical activity lead to the accumulation of adipose tissue mainly in the abdominal-visceral region. Visceral fat is metabolically active. Its cells produce a number of biologically active substances and are the site of synthesis of steroid hormone enzymes. High metabolic activity of visceral adipose tissue is also associated with the presence of a high density of $\beta_{3}$-adrenoceptors, corticosteroid, androgen receptors in adipocytes, and a relatively low density of $a_{2}$-adrenoceptors and insulin receptors. An increase in the volume of visceral adipose tissue leads to active lipolysis, which is accompanied by the formation of large amounts of free fatty acids (FFA), the synthesis of proinflammatory cytokines (interleukin-6 (IL-6), interleukin 1 beta (IL-1ß), tumor necrosis factor (TNF-a)) and the development of chronic systemic inflammation. All these events lead to the development of IP - a condition characterized by a decrease in the sensitivity of peripheral tissues to the insulin action. The results of a detailed analysis of the scientific literature allow us to assert that the study of molecular mechanisms of IR induction is of great practical importance for the improvement and development of new methods for the diagnosis and treatment of people with owerweight adipose tissue. The study of molecular mechanisms in the IP development is of great practical importance for improving and developing the new meth- ods for diagnosis and treatment of individuals with increased adipose tissue content. The biochemical and morphological features of adipose tissue structure, its metabolic activity, and the cellular mechanisms determining the formation of IR at receptor and postreceptor levels were clarified in this review. The data on the involvement of the inflammatory process in the development of IR were presented.

Keywords: insulin resistance, abdominal-visceral obesity, adipocytes, inflammation, pro-inflammatory cytokines.

Для цитування: Левчук НI. Біохімічні та молекулярні механізми розвитку інсулінорезистентності в клітинах жирової тканини. Ендокринологія. 2020;25(3):243-250. DOI: 10.31793/16801466.2020.25-3.243.

Відомості про автора: Наталія Іванівна Левчук, канд. біол. наук, старш. наук. співр., ORCID: 0000-0003-0482-5176.

Особистий внесок: Н.І. Левчук - аналіз літератури і підготовка статті.

Фінансування: стаття підготовлена в рамках бюджетного фінансування Національної кадемії медичних наук України.

Декларація з етики: автор задекларував відсутність конфлікту інтересів і фінансових зобов'язань. 